\title{
Mapotecas en Santiago de Chile: regímenes de visibilización del corpus cartográfico y sus mediaciones conceptuales y materiales ${ }^{1}$
}

\author{
Alejandra Vega ${ }^{2}$
}

\begin{abstract}
RESUMEN
Un acercamiento bibliográfico y etnográfico a cuatro de las principales mapotecas de Santiago de Chile (Mapoteca del Archivo Nacional, Mapoteca de la Biblioteca Nacional, Mapoteca de la Facultad de Arquitectura y Urbanismo de la Universidad de Chile y Mapoteca del Instituto Geográfico Militar) permite discutir cómo se visibiliza ante los usuarios el corpus cartográfico resguardado por estas instituciones. En la articulación entre una determinada comprensión de la naturaleza del mapa y una materialización específica de las formas de mediación entre mapas y públicos, las mapotecas instauran regímenes de visibilización y ofrecen a los públicos que las consultan paisajes cartográficos preferentes, entendidos estos como configuraciones de figura, fondo y encuadre a partir de puntos de vista particulares, que habilitan o propician ciertas formas de observar la colección.
\end{abstract}

Palabras clave: Mapoteca, mediación, cultura material, paisaje cartográfico.

\section{ABSTRACT}

Through a bibliographic and ethnographic approach to four Map Rooms or Map Collections in Santiago, Chile, we discuss the visibilization of cartographic material. We study the following Map Rooms: Mapoteca, Archivo Nacional; Mapoteca, Biblioteca Nacional, Mapoteca, Facultad de Arquitectura y Urbanismo, Universidad de Chile; and Mapoteca, Instituto Geográfico Militar. According to our undersanding, this visibilization is informed by a particular understanding of the nature of maps as well as by the material mediations involved in the ways maps are presented to the their public. Thus Map Rooms offer specific cartographic landscapes to those who consult them, as maps appear to the public in specific configurations of figure, background and framing.

Key words: Map room, mediation, material culture, cartographic landscape. 
Un mapa ilustra la portada de "Archivos en Chile: miradas, experiencias, desafíos", una obra editada en 2016 por el Comité Nacional de la Memoria del Mundo. Se trata, según la información que puede observarse en la imagen reproducida, de un mapa de "Guañaco Millao i otros"; una "copia fiel" que lleva el timbre de la "Comisión Radicadora de Indíjenas - Temuco", el que consigna igualmente una fecha: octubre 10 de 1914. El mapa se inscribe en una o más series al identificarse como "Esp. N³", y por medio de los rótulos "Catorces -14-" y "veinticinco 25", inscritos con grafías y tintas diferentes. En la página de créditos de la publicación puede leerse lo siguiente: "Plano de deslindes en Collico, Departamento de Collipulli, 1884, Archivo General de Asuntos Indígenas, Título de Merced No 3 Guañaco Millao y otros" (Comité Nacional de la Memoria del Mundo, 2016: 1).

El libro y su portada me permiten introducir el objeto del presente artículo: la existencia de mapas en algunos archivos y bibliotecas y, más particularmente, la presencia de mapotecas en ellos. Pensar las mapotecas como problema de investigación permite poner en diálogo un repertorio amplio de problemas epistémicos e históricos que abarcan, entre otros, las prácticas de la producción cartográfica y su relación con los quehaceres del archivo y la colección; y, de manera complementaria, las vinculaciones entre estas prácticas y la utilización de mapas por parte de diferentes actores y sectores; la socialización e institucionalización de ciertas ontologías del mapa; y unas historias institucionales específicas.

En esta ocasión, me interesa desarrollar un aspecto específico de este problema que se configura en la intersección entre las ideas subyacentes acerca de qué es un mapa, las lógicas de organización de las mapotecas y las materializaciones específicas de dichas opciones. Sostenemos que tanto las ideas como su encarnación en instrumentos y prácticas situadas son claves para comprender cómo se opera institucionalmente con estos materiales y, por consiguiente, cómo se disponen para la interacción con los públicos que concurren a su consulta.

Aunque aun insuficientemente explorado, el campo de estudio de las mapotecas se ha desplegado al menos desde tres perspectivas: como una de las dimensiones del estudio de la historia de la cartografía; en la forma de investigaciones de caso de colecciones o coleccionistas; y en el campo del saber profesional de archiveros y bibliotecólogos. En tal sentido, puede situarse en diálogo con otros campos que han tenido un importante desarrollo en las ciencias sociales y las humanidades de las últimas décadas. Me refiero a la historia crítica del saber geográfico, a la historia de la producción del libro, las bibliotecas y las prácticas lectoras, a las reflexiones históricas y epistemológicas acerca del archivo, la colección y el coleccionismo, a los estudios de cultura material y visual, y al más reciente campo constituido en la intersección entre patrimonio, memoria y ciudadanía. Como podrá observarse, las preguntas planteadas en este artículo pueden reconocerse en diálogo con muchas de estas otras esferas de indagación.

En este horizonte, propongo mirar las mapotecas como instituciones creadas al alero de una visión particular de los mapas concebidos como "representaciones perfectibles del mundo geográfico" (Woodward y Lewis, 1998: 1)3․ Esta visión naturaliza el mapa como "espejo del mundo"4.

Traducción propia

Tomo esta expresión como referencia a la comprensión habitual de la "naturaleza de los mapas", en palabras de Harley (2001: 35). Carla Lois (2014), indaga en las acepciones corrientes presentes en el Renacimiento para pensar el mapa como espejo y las metáforas que estas habilitan. Me interesa, en particular, aquella ejemplificada por Lois en el texto de Jacques Focard, quien escribió que "así como por el astrolabio se tiene conocimiento de los cielos, por el espejo o mapamundi se lo tiene sobre a tierra y sus partes" (citado en 41). 
Aun cuando se acepte que el mapa se elabora de acuerdo a los conocimientos y el manejo técnico que se posee en un momento dado, se asume una relación no problemática entre el mundo y el objeto cartográfico en el que este se "refleja" y, desde esa metáfora, se le reduce ya sea a la condición de huella susceptible de adquirir valor patrimonial o a su condición utilitaria, contingente. En tanto objeto patrimonial, es huella de formas pasadas, imperfectas, ya superadas, de la representación del territorio, y como tal, puede situarse en una historia lineal de la cartografía. En su condición de instrumento, el mapa apoya o expresa "la planeación económica, [el] aprovechamiento de los recursos naturales y [el] control de la tenencia de la tierra"5. Como puede reconocerse, estas ideas confluyen en la comprensión de la producción cartográfica como expresión de una historia del progreso y el perfeccionamiento técnico, y de las mapotecas como depositarias de esa historia particular y de su permanente actualización.

Sugiero que esta visión del mapa - naturalizada, instrumental, perfectible y en continuo proceso de perfeccionamiento - permea las prácticas de la formalización de las mapotecas y sus procesos de inventario, catalogación y creación de instrumentos para la consulta ${ }^{6}$. Como resultado, se funden e invisibilizan dos modos de constituirse el corpus cartográfico: el de la colección y el del archivo. Esta propuesta recoge y explora una idea enunciada por Harley, quien apuntó al efecto de las mapotecas en la historia de la cartografía como campo de conocimiento, impactado por las prácticas de catalogación y de exhibición de estas instituciones (1987: 15)7.

Por otra parte, me interesa indagar en el peso de lo material en la configuración de lo visible. Los mapas en tanto imágenes del territorio, y las ideas que tenemos acerca de ellos, se nos presentan como objetos con una existencia histórica específica, una vida social que supone trayectorias compartidas o excepcionales, en coexistencia con otros objetos (Appadurai, 1991; Olsen, 2003). En consecuencia, seguir sus trayectorias en tanto objetos custodiados y puestos a disposición de un público particular permite igualmente tomar nota de lo que nos muestran.

Desde la articulación de estas dos dimensiones entretejidas e inseparables proponemos que las mapotecas constituyen regímenes de visibilización y ofrecen a los públicos que las consultan paisajes cartográficos posibles, entendidos estos como configuraciones de figura, fondo y encuadre con características propias a partir de puntos de vista específicos (Gombrich, 1984: 116). Al modo del paisaje en la pintura, se trata de un artificio, pues el corpus cartográfico así inscrito se da a ver enfatizando ciertos rasgos y sus correlaciones; $y$, tal como el paisaje, provoca un efecto particular en el observador ${ }^{8}$.

En su condición de propuesta indagatoria sobre un campo hasta ahora poco estudiado ${ }^{9}$, el presente artículo avanza en la contrastación parcial de estas hipótesis en relación con cuatro

Información obtenida del sitio "Mapoteca Manuel Orozco y Berra", https://www.gob.mx/siap/articulos/mapoteca-manuel-orozco-y-berra-27322.

Aunque no se hará referencia a estos procesos, puede suponerse que inciden también en los procedimientos de descarte y adquisición.

Véase igualmente las reflexiones de Jacob acerca de las transformaciones a través del tiempo entre uso, valoración y conservación de los mapas (1992: 56)

8 Sobre la condición de artificio del paisaje, el ocultamiento y desaparición (brouillage y éffacement) de las marcas del autor, ver asimismo Cauquelin (2000: 108 y ss). Besse apunta a la idea de un todo armonioso y ordenado, visto a distancia, desde arriba (Besse, 2000: 52)

En el campo disciplinario de la geografía en Chile, incluso la cartografía ocupa un lugar secundario. Ver, como indicio de ello, Hidalgo et at, 2015, quienes sostienen que solo un 4\% de los artículos publicados en la Revista Norte Grande entre 1974 y 2014 abordan temáticas cartográficas (12). Y en este marco cuantitativamente minoritario, la historia de la cartografía en su vertiente crítica, está prácticamente ausente, no solo de dicha publicación, sino del campo de la producción académica en términos generales. 
mapotecas fundamentales existentes en Chile: la Mapoteca del Archivo Nacional de Chile, la Mapoteca de la Biblioteca Nacional de Chile, la Mapoteca de la Facultad de Arquitectura y Urbanismo de la Universidad de Chile, y la Biblioteca y Mapoteca del Instituto Geográfico Militar.

\section{Mapas y mapotecas}

Hemos señalado que en la conformación de las mapotecas late o se expresa una asunción acerca de la ontología o el ser del mapa ${ }^{10}$, que lo piensa como un documento científico, no problemático, que representa información espacial. Se trata de un paradigma empiricista, que se consolida en el siglo XVIII, momento en el cual los hacedores de mapas - denominados cartógrafos a partir del siglo XIX- se reconocen a sí mismos como el resultado de una tradición que había llevado a perfeccionar la calidad y la cantidad de los contenidos cartográficos (Edney, 2005: 15).

Mapas hay en numerosas instituciones que custodian objetos de cultura -museos, bibliotecas, centros de documentación, archivos- donde ocupan un lugar específico en relación con otros objetos o documentos tales como manuscritos, documentos bibliográficos impresos, registros visuales, sonoros o audiovisuales, digitales y micrográficos, además de otros específicamente tridimensionales"1. Al mismo tiempo, también hay mapas en numerosos organismos que producen diferentes tipos de soportes cartográficos o que recurren a ellos como parte de su quehacer, donde también conviven con otros registros que pueden ser fotográficos, estadísticos, descriptivos, por citar solo algunos.

Una mapoteca es más que eso. Se trata de una unidad al interior de una de estas instituciones, sea servicio o sección, sala o colección, que de manera explícita se propone la custodia, conservación y puesta a disposición del público de material cartográfico, es decir, no solo mapas como hojas sueltas o en cuadernillo, sino también atlas, globos terráqueos, planos, mapas tridimensionales, etc. ${ }^{12}$. En el mundo anglosajón, estas instituciones se denominan de diversas maneras: Map Room, Map Reading Room, Map Collection o Map Library ${ }^{13}$. En el caso del francés, encontramos, entre otros, departamentos, servicios y colecciones de Cartes et Plans ${ }^{14}$.

10 Tomo estas expresiones del trabajo de Descola (2006) sobre la ontología de la imagen, y las preguntas que él plantea acerca de las relaciones entre artífices, objetos y mundo. Tal como sugiere Descola, la visión naturalista asume que el objeto/imagen -en este caso mapa- representa el mundo exterior o referente, haciendo impertinente cualquier pregunta acerca de la agencia del mapa y las agencias de las formas socialmente instituidas o subjetivas/individuales de lectura del mismo.

Me refiero a los objetos que componen convencionalmente las colecciones de los museos.

12 "Es la mapoteca la unidad, dentro de la Biblioteca, que conserva los mapas, cartas, planos, atlas y material especializado en Geografía y ciencias afines. Este material está considerado en la Bibliotecología dentro de los materiales especiales y tiene que ser, por lo tanto, tratado con técnicas diferentes" (Miranda Espinoza, 1980: 14). En la página web de la Mapoteca Manuel Orozco y Berra, puede leerse la siguiente definición de mapoteca: "Colección de mapas geográficos debidamente clasificados y ordenados para la consulta del público" (http://mapoteca.siap. gob.mx/).

13 Ver, entre otros, University of Chicago Library Map Collection, https://www.lib.uchicago.edu/e/collections/maps/; Perry Castañeda Library Map Collection de la University of Texas Libraries, http://www.lib.utexas.edu/maps/; David Rumsey Map Collection, alojada en la Stanford University, https://www.davidrumsey.com/about/about; Geography and Map Reading Room, LOC, https://www.loc.gov/rr/geogmap/; Map Reading Room en The British Library, https://www.bl.uk/visit/reading-rooms/maps-reading-room.

14 Département des Cartes et Plans, BNF, http://www.bnf.fr/fr/la_bnf/dpt_cpl/s.actualites_cartes_plans.html; Service de Cartes et Plans de la Bibliothèque de Genève, http://institutions.ville-geneve.ch/fr/bge/collections/cartes-et-plans/presentation/, Serie Cartes et Plan des Archives Nacionales de France, http://www.archivesnationales.culture.gouv.fr/chan/chan/series/serie-cartes-et-plans.html; Collection de Cartes et Plans de la Bibliothèque et Archives Nationales du Québec, http://www.banq.qc.ca/collections/cartes_plans/; entre otras. 
Sus procesos de constitución son resultado del quehacer de actores institucionales y personas, muchas veces articulados, y remiten a diferentes ámbitos de conocimiento, que abarcan desde la bibliotecología y la archivística hasta el saber propio del coleccionismo o el quehacer anticuario. Al hablar de la formación de mapotecas, hay al menos dos momentos que considerar, que no son momentos secuenciales o correlativos, sino momentos que se imbrican y codeterminan. Por una parte, el de la formalización de los corpus documentales que los constituyen. Y por otra, el de su descripción y catalogación.

Las mapotecas tienen una larga historia que las precede. Según la genealogía que se trace, esta puede llevarnos al siglo XIX, en que convergen los requerimientos de control territorial de las nuevas repúblicas nacidas de los ciclos de independencia colonial; el creciente interés de los estados por acoger las colecciones cartográficas nacionales; y la institucionalización de la geografía como campo del saber (Harley, 1987: 12-14). Podemos, igualmente, remontarnos al siglo XVIII, con la formalización de cuerpos de ingenieros militares en los ejércitos nacionales (Verdier, 2015); o incluso a los siglos XV y XVI con el desarrollo de los primeros proyectos coloniales modernos y de las primeras colecciones de mapas (Portuondo, 2013: 117-123) ${ }^{15}$.

En su mirada de la historia de la cartografía, Harley señala que la formación de mapotecas en instituciones como la Bibliotèque Nationale, el British Museum, y la Library of Congress responde a diversos intereses: "desde la necesidad de acoger, hasta las actividades complementarias de recolección de mapas de las diversas sociedades geográficas, la expectativa de establecer mapotecas ["map rooms"] en bibliotecas universitarias o en organismos de gobierno, así como las preocupaciones relativas a cuestiones militares y navales o concernientes a la administración de los espacios imperiales" (1987: 15) ${ }^{16}$. Su desarrollo más sistemático, sin embargo, se puede observar con posterioridad a la Segunda Guerra Mundial, en las décadas de los 50 y 60, impulsadas por la provisión de nuevos mapas, el acercamiento del campo de la cartografía y la disciplina geográfica; y el desarrollo de asociaciones y sociedades cartográficas, con la participación de curadores de mapas (Parry y Perkins, 2001: 1-2).

Parafraseando a Edney, quien discute el desarrollo del campo específico de la historia de la cartografía, y las miradas de bibliotecarios y archiveros, historiadores y geógrafos, coleccionistas y comerciantes de mapas, podría decirse que la formación de mapotecas -el reconocer, reunir, organizar y describir mapas- ha tenido como horizonte fundamental la identificación del contenido de estos; a saber: la identificación del territorio cartografiado (Edney, 2005: 14-15). Esto, que puede parecer a primera vista como obvio, lo es justamente porque moviliza una ontología del mapa, es decir, una idea que hemos naturalizado de lo que es el mapa como objeto.

\section{Colecciones y fondos de archivo}

Hemos propuesto que la mapoteca se sustenta en una idea determinada de la ontología del mapa -el mapa como documento científico o precientífico- que aúna o invisibiliza las formas de

Harley señala que la catalogación se sistematiza a comienzos del siglo XX, aunque pueden rastrearse los procesos de catalogación en bibliotecas del siglo XVII y XVIII (1987: 19-20)

16 Traducción propia. 
comprender la constitución de los corpus cartográficos que resguarda: la colección y el archivo. Esta yuxtaposición de corpus con historias formativas diferenciadas afecta, hasta el día de hoy, nuestras lecturas de este material.

Veamos lo que esta distinción supone:

Desde la museología, la colección puede definirse como

"un conjunto de objetos materiales o intangibles (objetos, artefactos, "mentefactos", especímenes, documentos de archive, testimonios, etc.), que han sido reunidos, clasificados, seleccionados y preservados por un individuo o institución en un espacio seguro y destinados, habitualmente, para su exhibición para una audiencia restringida o amplia, según se trate de una colección pública o privada" (Desvallées y Mairesse, 2010: 26).

Desde una visión centrada en el repertorio documental, la archivística comprende la colección como "conjunto de unidades documentales o componentes documentales, de igual o distinta procedencia, reunidos por motivos de conservación, por su especial interés o por cualquier otro criterio subjetivo" (CNEDA, 2017: 12).

Cuando hablamos de colección, y parafraseando a Baudrillard (1999), nos referimos a una unidad conformada y organizada desde criterios específicos, cuya coherencia está dada por la aplicación de estos criterios sobre unos objetos que son abstraídos -al menos parcialmente- de sus funciones y de los sucesivos contextos en los que estos se produjeron o circularon. Su significado queda de este modo anclado a una operación de segundo orden, que moviliza una pasión privada, subjetiva, localizada, extemporánea o anacrónica, diferente de aquella que constituyó los significados primarios del objeto antes de su colección; un nuevo significado que adquiere, sin embargo y por efecto de su validación institucional, un carácter de verdad atemporal.

Me interesa destacar que la práctica de la colección de mapas integra al menos dos dimensiones. Por una parte, encarna el mandato del conocimiento humanista como un horizonte integrado, capaz de constituir un catálogo potencialmente completo del mundo, vinculado con el ideal burgués moderno. Por otra parte, moviliza dicho mandato en relación con funciones ideológicas y retóricas específicas destinadas a reconocer y validar un territorio o un conocimiento del territorio, perfeccionado en el tiempo por efecto del desarrollo de la ciencia y la tecnología. Y, más particularmente, moviliza este mandato para asegurar la función estatal -históricamente perfilada y desplegada- por medio de organismos técnicos específicos en atención a los agentes del estado, los ciudadanos y la formación escolar (Harley, 2001: 59-60; Anderson, 1991: 243-244).

Las mapotecas contienen como puede suponerse, colecciones de mapas. Pero las mapotecas albergan igualmente fondos de archivo o, en su defecto, mapas provenientes de fondos de archivos.

Este segundo término, remite de manera específica a un "[c]onjunto de documentos producidos por un agente en el ejercicio de sus funciones" (CNEDA, 2017: 18). El motor de constitución del fondo es la acción desplegada por diferentes agentes (personas naturales o instancias colectivas, personas jurídicas privadas o públicas) y su huella documental. El fondo contiene material documental que ha sido "reunido, creado, acumulado y/o utilizado [...] en el desempeño de 
su quehacer" (Bureau of Canadian Archivists, 1992, citado en Desvallées y Mairesse, 2010: 26)17. Constituidos como series, los documentos resultan elocuentes porque pertenecen a un corpus mayor y por su posición al interior de este: "como principio general, las piezas aisladas (documentos sueltos) no tienen sentido o tienen muy poco, su razón de ser viene dada por su pertenencia a un conjunto -la unidad archivística o dependiente- y por las relaciones establecidas entre si" (Cruz Mundet, 2011: 29).

La instancia de su producción -y no el ojo del coleccionista- organiza el material. Sin embargo, en este caso también operan -evidentemente- posicionamientos ideológicos y asunciones epistemológicas, por lo que debe precisarse el modo en que se define el carácter "automático", "natural" o "no intencionado" del archivo. Tiene sentido pensar el archivo como formación discursiva que refleja las categorías y operaciones del Estado mismo (Dirks, 2002 citado en Muzzopappa y Villauta, 2011: 30), del mismo modo que aparece el coleccionista como movilizador de categorías de organización de los materiales y, en un sentido mucho más amplio, de lo sensible. Lo importante de retener, para esta discusión, es que los posicionamientos ideológicos y epistemológicos que modulan la conformación del archivo operan, en primer término, en el momento de su producción siendo fundamental el que los documentos de archivo se conservan "respetando el orden según el cual fueron creados, manteniéndolos ligados por un vínculo necesario" (Cruz Mundet, 1994: 94).

Estas dos lógicas de constitución de corpus documentales se funden, y se confunden, pues las mapotecas, aunque se constituyen a partir de fondos y colecciones, en su gestión documental tienden a privilegiar la lógica de la colección. Es acá donde la idea del mapa naturalizado entra en acción: dado que los mapas se conciben como expresiones de una secuencia en la representación perfectible de la superficie terrestre, su organización opera a partir del principio del referente - el espacio representado- el cual se constituye en el modo privilegiado de organizar y poner a disposición del público este material. Ya no es ni el deseo del coleccionista, ni el quehacer de la persona o institución la que se visibiliza respecto del corpus de documentos resguardados, sino que operan sobre ellos nuevos ordenamientos para relevar la secuencia y recurrencia de representaciones de un determinado territorio.

Por otra parte, estas ideas se materializan de formas diversas, en función de unas historias institucionales expresadas en espacios, mobiliarios, categorías de descripción encarnadas en catálogos, prácticas de interacción con el material y con los usuarios potenciales o efectivos, sean estos categorizados como la ciudadanía, los estudiantes, los investigadores especializados, etc. De modo que -para un mismo repertorio conceptual-, podemos encontrar prácticas efectivas diferenciadas a la hora de reconocer, valorar y visibilizar el material cartográfico.

Habiendo establecido el problema a tratar, propongo entonces un acercamiento documental y una etnografía primera y tentativa de cuatro mapotecas de Santiago de Chile. Tomamos esta expresión del trabajo de Muzzopappa y Villalta, quienes realizan una etnografía de los archivos como modo de acercamiento a la comprensión de las tradiciones y lógicas que movilizan distintos actores para la construcción de conocimiento (en su caso, para discutir nuevas aproximaciones al estudio del campo de lo estatal). Su planteamiento contempla atender a "las formas que 
accedemos, los recorridos que debemos realizar, y la contextualización histórico-política de los documentos" (2011: 30). En el caso de este artículo, el foco estará puesto en la observación y el registro de las diferentes prácticas que conectan usuarios y documentos cartográficos en las mapotecas, los que nos permiten poner de manifiesto las opciones que subyacen a la existencia de estas instituciones y los efectos de conocimiento que conllevan estas opciones históricamente materializadas. Hemos optado por pensar estas prácticas como mediaciones dialécticas en tanto constituyen no simples interfases, sino momentos o instancias de producción de significados ${ }^{18}$.

\section{Mapotecas en Santiago de Chile}

La creación de mapotecas en Chile puede pensarse como la materialización local de una práctica transnacional que involucra diferentes dinámicas y agentes estatales, científicos y privados. Contra una idea difusionista, me parece pertinente pensar en las necesidades específicas que movilizan ciertos actores en diálogo con tendencias y posicionamientos que se adoptan en otros espacios cercanos o distantes. Quedará para un trabajo posterior la comprobación efectiva de la propuesta recién enunciada, siendo esquivas las huellas que permiten reconocer las motivaciones, los mandatos, las tradiciones y lógicas efectivas que llevan a la formación en Chile de estas mapotecas, en el marco de políticas internas de manejo de colecciones especiales, de desarrollo de servicios de consulta específicos y/o de expresión de la puesta en valor de los tesoros bibliográficos o documentales que resguardan las instituciones.

Hoy referentes regionales insoslayables, algunas de las principales mapotecas de América Latina parecen desarrollarse de manera contemporánea a las que existen en Santiago de Chile. Con colecciones cuyos primeros ejemplares datan del periodo colonial, estas mapotecas se formalizan unas a fines del siglo XIX y otras en el transcurso del siglo XX. Así, la Mapoteca Manuel Orozco y Berro en México, formada al alero del Ministerio de Fomento durante el Porfiriato, fue bautizada así en 1977, año que recibe además la colección cartográfica del Instituto Panamericano de Geografía e Historia ${ }^{19}$; la Mapoteca Manuel Selva de la Biblioteca Nacional de Argentina, aunque nombrada posteriormente de este modo en honor a quien realizara su primer catálogo en 1941, tiene espacio propio desde 194020; la colección cartográfica de la Biblioteca Nacional de Brasil se materializa como División de Cartografía en 1998, al separase de la sección Iconografía de la Biblioteca, que albergaba el acervo cartográfico hasta entonces (Acervo, 2016: 14); la Mapoteca del "Instituto Histórico Geográfico Brasileiro", de cuyo funcionamiento se tiene registro desde la década de 1960 (Luzes); mientras la Mapoteca de la Biblioteca Nacional de México se crea en 1979²1.

De manera explícita, el trabajo desarrollado en la División Geográfica y de Mapas de la Biblioteca del Congreso de Washington (Geography and Map Division, Library of Congress) se constituye como un referente fundamental para el desarrollo de las mapotecas del continente ${ }^{22}$.

\footnotetext{
Para una discusión del concepto de mediación desde una posición no dualista, véase Williams (1977).

Información obtenida del sitio web http://mapoteca.siap.gob.mx/

Información obtenida del sitio web https://www.bn.gov.ar/biblioteca/salas/mapoteca

Información obtenida del sitio web http://bnm.unam.mx/index.php/fondo-contemporaneo/sala-de-mapoteca

Para el caso de Chile, véase los apuntes del curso dictado por Miranda Espinoza acerca de la organización de la unidad "Mapoteca", (1980: 14); para el caso mexicano, se puede consultar el trabajo de Abell $(1977: 124,130,134)$.

La Library of Congress adquiere mapas y atlas desde los años iniciales de funcionamiento de la biblioteca, y en 1897 se crea una mapoteca separada. Información obtenida del sitio web https://www.loc.gov/rr/geogmap/gmhist.html
} 


\section{Mapoteca del Archivo Nacional}

Veamos entonces las cuatro mapotecas elegidas para este trabajo, comenzando con la Mapoteca del Archivo Nacional. Esta fue creada en 1974 por Patricio Estellé, nombrado conservador del Archivo Nacional en septiembre de $1973^{23}$, luego del Golpe militar, aunque queda por determinar si la Mapoteca se trató o no de un proyecto heredado de la administración anterior. Se estima que reúne hoy cerca de 3.000 piezas, de las cuales 1.400 están digitalizadas ${ }^{24}$. De acuerdo con la descripción institucional, "[c]ontiene mapas, planos de predios, de casas o edificios públicos, puentes, fortalezas, minas, ciudades, sistemas de regadío, etc., todos ellos originales" (Archivo Nacional, 1983: 118). Compuesta mayoritariamente de mapas correspondientes al periodo colonial, la colección ha seguido ampliándose con nuevas donaciones documentales que llegan al Archivo Nacional, y que muchas veces tienen mapas. Unos pocos de ellos son más conocidos, pues han sido reproducidos a modo de ilustración en diferentes publicaciones académicas, escolares o de difusión (por ejemplo, los mapas manuscritos de Claudio Gay de 1842) o integrados en exposiciones temporales que organiza el Archivo o la Biblioteca Nacional.

Los materiales cartográficos de la Mapoteca del Archivo se encuentran en depósitos, fuera de la vista de los usuarios, en un espacio reservado a los funcionarios de la institución. Se alojan en planeras y estanterías cuya clasificación interna articula, según los casos, los tamaños de los mapas, los números de inventario o los números de catalogación que pueden guardar alguna relación con ciertos temas ${ }^{25}$. Algunos están sueltos, dispuestos unos sobre otros en los cajones de las planeras, lo que permite mirarlos al recto y al verso; mientras otros fueron entelados en el pasado, quizás para alguna exposición temporal o en vistas de su conservación, con procedimientos poco acordes con la fragilidad del papel, afectando quizás para siempre su condición material.

En esos muebles, esos pasillos y esos espacios se forma, circula y se transmite un conocimiento que comparten quienes trabajan en el Archivo, y que recorren no solo los instrumentos de consulta, como nosotros los usuarios (Figura $N^{\circ} 1$ ). Como ha evidenciado Fortey (2008) en relación con Museo de Historia Natural de Londres, la institución y sus colecciones adquieren nuevas dimensiones cuando estas se observan en el tránsito entre espacios públicos y reservados, que constituyen la experiencia de los trabajadores de un museo o archivo. Se trata de tránsitos formalizados por medio reglas y prácticas -heredadas y nuevas- que cristalizan en saberes significativos respecto de los bienes resguardados por la institución. Aunque no sistematizable, no puede dejar de mencionarse en este caso que los funcionarios del Archivo Nacional, sus sugerencias, preferencias, y opiniones, son mediaciones fundamentales en nuestro acceso a la mapoteca y en los paisajes cartográficos que en esta se configuran.

Al mismo tiempo, como usuarios, contamos con las materializaciones de los instrumentos de descripción. Hoy se accede a la Mapoteca por tres medios: a través del catálogo digital del Archi-

\footnotetext{
Revista Qué Pasa, Patricio Estellé [Obituario]. Información obtenida del sitio web http://www.bibliotecanacionaldigital.cl/bnd/628/w3-article-223974.html

24 Información obtenida del sitio web http://www.bncatalogo.cl/F/?func=find-b-O\&local_base=ARNma. Véase además http://www.archivonacional.cl/sitio/Secciones/Servicios/Mapoteca/

25 Según información de visita a la institución, mayo de 2015.
} 
Figura $\mathrm{N}^{\circ} 1$

Depósito del Archivo Nacional. Colección cartográfica de Fondo "Salitre de Chile"

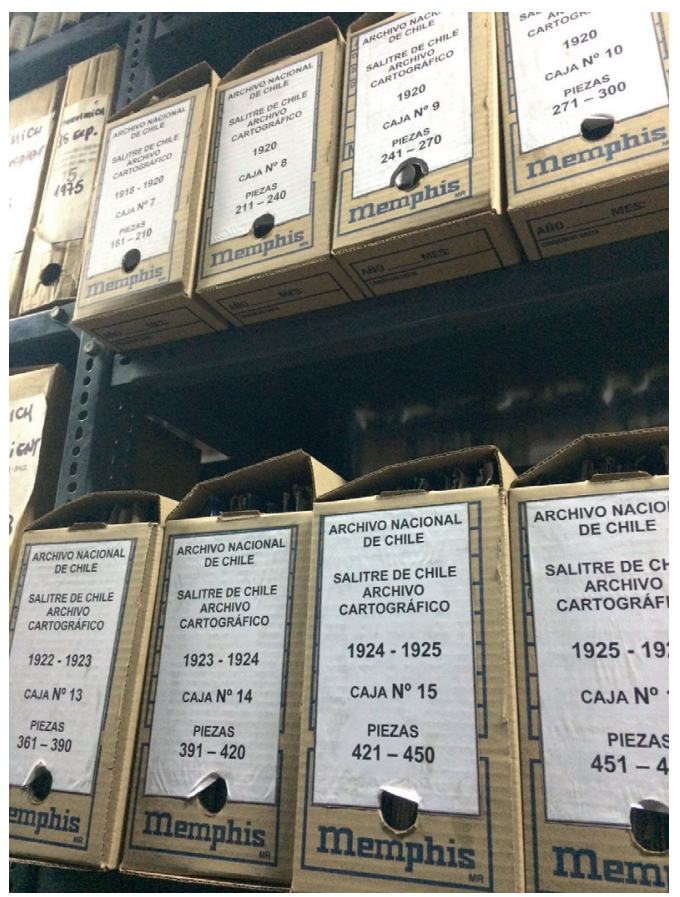

Fuente: Archivo fotográfico personal de la autora.

vo; por medio del mueble fichero que contiene tarjetas de cartón, ubicado en la sala de lectura del Archivo; y a través de un catálogo anillado.

El catálogo digital de la Mapoteca corresponde a una sección del catálogo general del Archivo Nacional (http://www.archivonacional.cl/sitio/Secciones/Catalogos/), el cual se encuentra a su vez integrado a la plataforma de la Biblioteca Nacional de Chile (http://www.bncatalogo.cl/F/?func=find-b-O\&local_base=ARNma). La plataforma permite realizar búsquedas básicas por campos, que son las mismas que para toda la plataforma de consulta ${ }^{26}$, y lleva a una ficha de catalogación. Esta contiene algunos campos específicos, como "lugar", en el que se consigna el territorio cartografiado y "productor", donde se indica el Fondo documental del cual proviene la pieza y el volumen del cual fue extraído.

La mapoteca se nos presenta asimismo mediante el fichero de tarjetas de cartón, el cual está ordenado alfabéticamente por topónimos y que posee una amplia sección, correspondiente a casi un cuarto de las fichas, sin clasificar (Figura $N^{\circ} 2$ 2). Según información oral disponible, el fichero sería el instrumento de consulta más antiguo disponible ${ }^{27}$. Aunque no hicimos un conteo preciso, todo sugiere que el fichero no contiene las 3.000 piezas que se contabilizan institucionalmente.

\footnotetext{
Título, autor, materia, ISBN, año, editorial número de sistema.

27 Según información de visita a la institución, realizada en mayo de 2015.
} 
Figura $\mathrm{N}^{\circ} 2$

Fichero de fichas en papel de la Mapoteca del Archivo

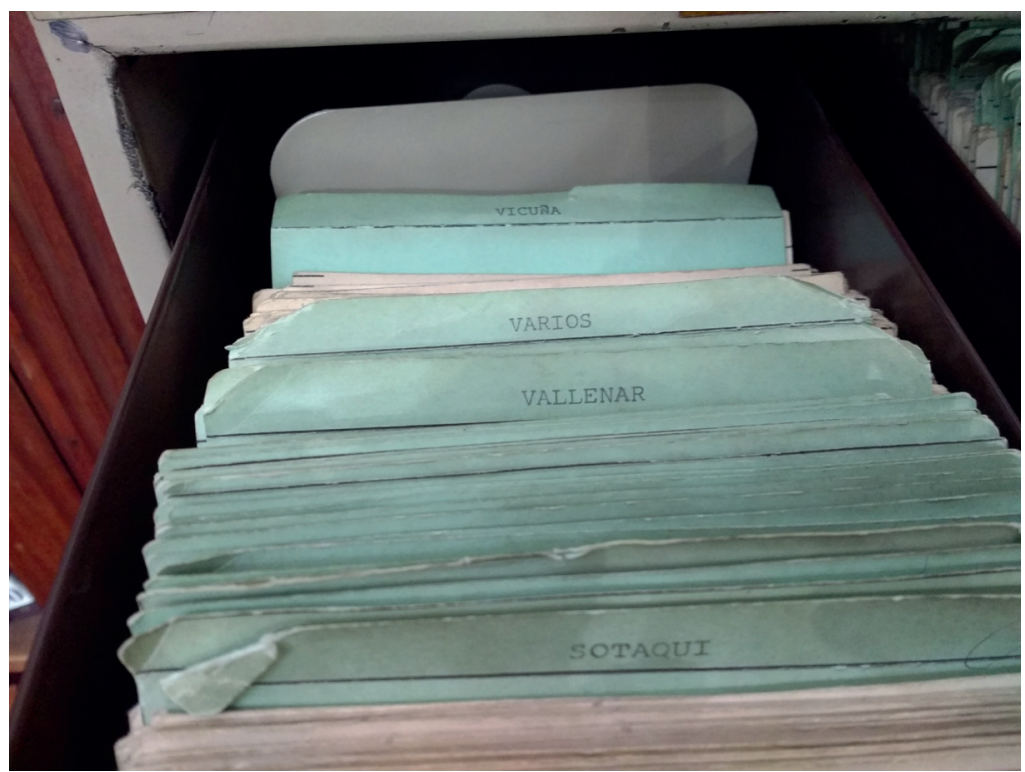

Fuente: Archivo fotográfico personal de la autora.

Por último, existen un catálogo anillado cuyo título es "Mapoteca. Catálogo de planos, mapas y croquis del Archivo Nacional Histórico. Siglos XVIII-XX". Se trata una obra mecanografiada y anillada en dos tomos, y foliada, de 424 páginas. Contiene el registro de casi 900 mapas, con un número de inventario consecutivo que no tiene un orden evidente al observador (fondo, tema ni fecha). Acá se consigna información individual de cada pieza que es similar, aunque no idéntica, a lo consignado en los otros instrumentos de consulta, ordenadas en esta ocasión temáticamente: vías de comunicación, predios agrícolas, fortificaciones, etc.; organización que queda puesta en valor en un índice temático al final del segundo volumen.

De modo que, en el caso de la Mapoteca del Archivo Nacional, vemos operando mediaciones materiales en el acceso a los mapas que poseen, por una parte, temporalidades diferenciadas, y por otra, efectos muy diversos de visualización del corpus. Lo que resulta son, potencialmente, diferentes paisajes cartográficos según el medio empleado para acceder a la colección, pues cada uno enfatiza -o encuadra y da realce, tal como en un paisaje- diferentes configuraciones de elementos. De gran potencial e impacto son las herramientas de búsqueda del catálogo en línea, que nos permiten identificar, por ejemplo, los trabajos de algunos de los cartógrafos cuyos nombres son conocidos y que firman sus obras. Al mismo tiempo, se puede acceder, localmente o a distancia, a la versión digital de piezas claves de la colección, permitiendo una circulación hasta ahora inimaginable de imágenes cartográficas, las que -como se ya se señaló-, estaban antes restringidas a las decisiones de editores escolares o generales, o curadores de exposiciones que relevaban y ponían en circulación unos mapas por sobre otros. Se multiplican así los referentes 
posibles de una cultura visual sobre el territorio ${ }^{28}$. Pero, por otra parte, el fichero en papel y el catálogo anillado permiten recorrer con la mirada y tener una percepción más clara de la colección, aun estando estos instrumentos incompletos. Al darse el trabajo de leer una a una las fichas, se provee una visión de conjunto que queda oculta bajo la ventana de consulta de la plataforma digital y sus criterios de búsqueda.

Al mismo tiempo, todas estas mediaciones plantean el problema de la relación del documento con la serie, característica fundamental de los materiales correspondientes a fondos de archivo. Según recoge la propia institución:

"Ha sido regla general [...]observar el llamado principio de origen. Se respeta la unidad que da origen a un grupo documental el provenir de conjuntos producidos por una misma autoridad o institución, sin causar en ellos cambios de ninguna naturaleza, efectuados so pretexto de crear conjuntos homogéneos, que no existieron en la realidad y que serían artificiales" (Archivo Nacional, 1983: 107).

Sin embargo, como ya se adelantó, al momento de su constitución, la Mapoteca sacó de los fondos lo que era material cartográfico, o al menos una parte de este:

"Se han retirado de los documentos del Archivo en que estaban anexos y falta todavía una revisión sistemática de todos los fondos en búsqueda de más mapas y planos" (Archivo Nacional, 1983: 118).

Al menos en el plano de los catálogos que habilitan nuestro contacto con la colección cartográfica en tanto usuarios, algunos de los mapas del Archivo siguen refiriendo a los fondos en los que se encontraban originalmente, tanto del periodo colonial como republicano: entre otros, leemos referencias a los fondos Real Audiencia, Capitanía General, Benjamín Vicuña Mackenna, Claudio Gay, Varios, Tribunal del Consulado, Antiguo, Municipalidad de Santiago, Ministerio del Interior, Ministerio de Educación, Ministerio de Marina, y Ministerio de Guerra. En algunos casos, se indica el volumen al cual pertenecía la pieza, pero no hemos encontrado referencias a la posición particular que el mapa ocupaba al interior del volumen. Por otra parte, muchos mapas no tienen indicación de fondo. De modo que, en la práctica, se ha roto ese vínculo fundamental de la huella documental y el legajo que lo acogió en su primera etapa de existencia material. Excepcionalmente, se registran otros tránsitos $u$ orígenes, como aquel consignado en la ficha relativa al mapa n 848, titulado "Llano del Maipo, año 1762, escala 3 leguas castellanas" en la cual podemos leer la siguiente inscripción: "Traspaso de la mapoteca de la Biblioteca Nacional a la Mapoteca del Archivo Nacional, 1982".

No son pocas las colecciones cartográficas en el mundo que enfrentan este problema: el de la separación del mapa de su primer contexto de producción y significación fruto de operaciones institucionales posteriores, y la necesaria reconfiguración de los significados que movilizan cada una de las piezas, en relación con sus nuevas circunstancias de habitación.

Esta multiplicación tiene numerosos efectos y ramificaciones, pues ver una imagen es mucho más que un ejercicio de percepción. Véase en Hollman y Lois (2015), la reflexión particularmente referida al uso de imágenes en la instrucción escolar (mapas, pero también fotografías, esquemas, etc.). 


\section{Mapoteca de la Biblioteca Nacional y colección cartográfica de la Sala Medina}

Pocos pasos separan la Mapoteca del Archivo Nacional de la Mapoteca de la Biblioteca Nacional, a la cual se ingresa por el frontis principal del edificio que comparten ambas instituciones en el centro de la ciudad de Santiago.

Hoy la Mapoteca tiene sala propia, la que se encuentra en el primer piso del edificio, en el hall central del acceso sur y se accede a sus colecciones por medio de terminales de computación ${ }^{29}$.

Detrás de una mampara que separa el espacio público del reservado, enormes planeras acogen una parte de la colección cartográfica de la Biblioteca (Figura No 3). El resto de este acervo se encuentra en las zonas de bodega reservada al personal institucional ${ }^{30}$.

Figura $\mathrm{N}^{\circ} 3$

Sala de Mapoteca de la Biblioteca Nacional, con planeras y repisas para colección bibliográfica

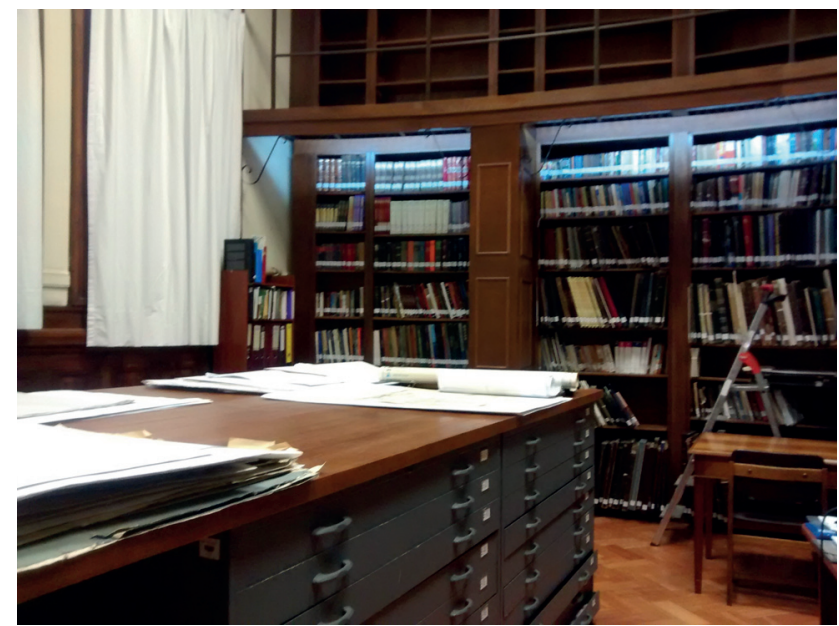

Fuente: Archivo fotográfico personal de la autora.

Esta es también una mapoteca actual, creada cuando Roque Esteban Scarpa ocupaba la Dirección de Bibliotecas, Archivos y Museos ${ }^{31}$, a partir de los materiales que existían previamente en la Biblioteca Nacional; e incrementada con los que han ido llegando con posterioridad a esa

29 Según la memoria de actividades de 1996-1997, en ese periodo se inaugura esta nueva sala: "Nueva sala para la mapoteca. Durante mucho tiempo, la mapoteca ocupó un mismo espacio junto a otras colecciones. En la nueva sala hay más espacio y, por lo mismo, mejores condiciones de trabajo, así como también, más facilidades para acceder al material cartográfico y a la base de datos da la cual ha sido incorporado, pudiendo así disponer de él con mayor facilidad, incluso a través de la red Internet. La colección de la sala reúne mapas de todo el mundo, pero es especialmente interesante la colección de mapas nacionales que incluye cartas geográficas e hidrográficas, así como los primeros planos fundacionales de las ciudades de Chile" (Biblioteca Nacional de Chile, 1998: 29)

30 Según información de visita a la institución, realizada en mayo de 2015.

31 El año de creación de la Mapoteca resulta elusivo. Varias de las publicaciones de la Biblioteca Nacional citadas en esta sección no lo mencionan; Biblioteca Nacional de Chile (1982) se da como fecha 1964, año que coincide con la gestión del director Guillermo Feliú Cruz; y Alarcón Apablaza y Guzmán atribuyen la creación a Roque Esteban Scarpa pero la fechan en 1968 (2006: 11). En conversaciones con la señora Ana María Quiroz, jefa de la Mapoteca, nos ha indicado que la fecha sería 1970 (visitas en mayo 2016 y enero 2018). 
fecha (Biblioteca Nacional de Chile, 1982; 129). Según leemos en el decreto que crea esta sección, se trataría de resguardar y difundir "las colecciones de mapas, planos, cartas topográficas, náuticas, etc. producidas en el país, para satisfacer las necesidades de información del usuario que requiere este material bibliográfico especializado" (Biblioteca Nacional de Chile, 2013: 128), los que se entregan fruto de la imposición del depósito legal luego de la fundación republicana, y se ha acrecentado por efecto de importantes donaciones decimonónicas y del siglo XX:

"La práctica del depósito es paralela a los orígenes mismos de la Biblioteca Nacional. En efecto, ya en 1818 don Manuel de Salas había establecido que de toda publicación editada en las prensas de gobierno se entregasen ejemplares a la Biblioteca para su conservación y para enviar en canje a Buenos Aires" (Biblioteca Nacional de Chile, 1989: 24).

Estas primeras disposiciones sufren cambios a través de los años, "conservando el espíritu de preservar el patrimonio impreso nacional" (Biblioteca Nacional de Chile, 1989: 24).

Como resultado, la Mapoteca "[c]onserva gran parte del patrimonio cartográfico nacional de los siglos XIX y XX [y XXI] y recibe -como depositaria- todas las publicaciones y ediciones cartográficas y geográficas de las dos instituciones oficiales en la materia: el Instituto Geográfico Militar y el Instituto Hidrográfico de la Armada" (Biblioteca Nacional de Chile, 2003: 73).

Una vez creada la Mapoteca, se separaron las piezas cartográficas que se encontraban, hasta entonces, en otras secciones de la Biblioteca, y solo se conservan huellas de esta historia de inscripciones institucionales por medio de los timbres y sellos con que se marcaron estas piezas en diferentes momentos de su historia material (Figura $N^{\circ} 4$ ).

Atlas, mapas ruteros y turísticos, mapas murales, incluso mapas publicitarios, y la cartografía oficial de Chile integran así el patrimonio de esta sección. Según se señala en la web institucional, el corpus lo componen hoy más de 9.000 títulos, cerca del 50\% de los cuales ha sido digitalizado ${ }^{32}$.

La catalogación de este corpus se realizó progresivamente al momento de su incorporación al acervo de la Biblioteca, por lo que se recurrió a los sucesivos soportes de catalogación que se fue proveyendo la institución a lo largo del tiempo. Los catálogos en volúmenes que contenían todas las referencias a obras impresas, incluidas las cartográficas, dieron paso a los ficheros con fichas de cartón y estos, a su vez, al catálogo digital. De esa primera transformación, da cuenta una crónica en "Zig-Zag" de 1926:

"Qué se han hecho esos catálogos? Ya no los hay. Existen unos cajones amarillos con unas tarjetas. Una tarjeta para cada volumen. Dicen que resulta más práctico, porque se pueden cambiar, quitar, añadir. Posiblemente. A los viejos lectores de entonces no les da lo mismo, no les despierta igual apetito. Tal vez porque no les traen recuerdos, no son viejos amigos..." (citado en Alarcón, 2013: 53).

\footnotetext{
32 Este número ha crecido de manera importante. Según publicación de 2003, la colección cartográfica contabilizaba 6542 títulos (Biblioteca Nacional de Chile, 2003: 73); mientras una publicación sin fecha, datada antes de 2013 (Biblioteca Nacional de Chile, s/f:17).
} 
Figura $\mathrm{N}^{\circ} 4$

Huellas materiales del paso de un mapa de la Biblioteca Nacional por diferentes secciones de la institución antes de su ingreso a la Mapoteca

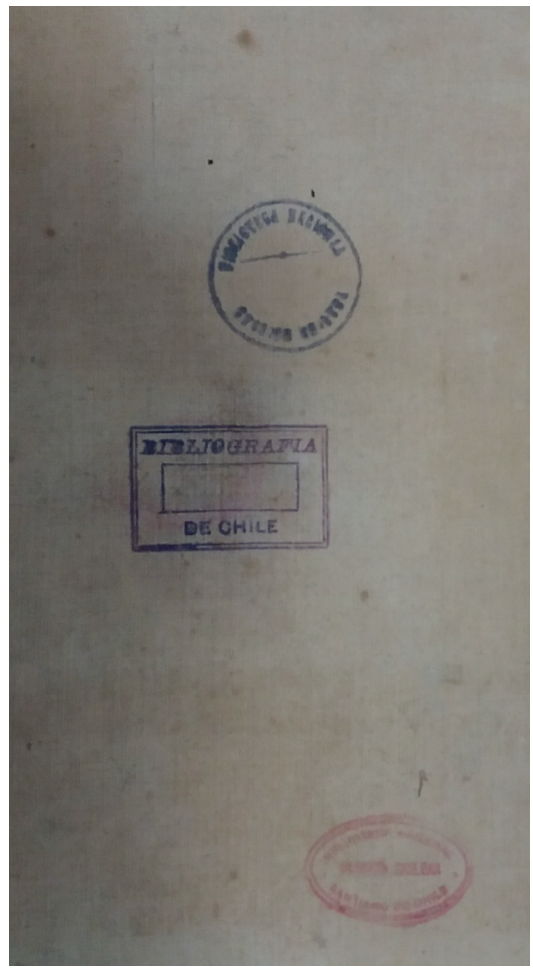

Fuente: Archivo fotográfico personal de la autora.

De la segunda transformación, nos informa una crónica de Alarcón, funcionario de la sección Referencias Críticas de la Biblioteca:

"Quienes atendieron a los "viejos lectores" de la década de mil novecientos noventa fuimos testigos de que ellos tuvieron idéntica desazón cuando los catálogos en fichas desaparecieron para dar paso al catálogo electrónico, consultable desde una computadora o un terminal, sea desde otra biblioteca o desde su propio escritorio" (Alarcón, 2013: 53).

Efectivamente, al consolidarse el catálogo digital desaparece no solo la sala de ficheros generales, sino también el fichero de tarjetas de cartón que se alojaba en la Mapoteca y que contenía el detalle de la colección cartográfica. Desaparece así, la huella material tangible de la totalidad del corpus de la colección de mapas. El catálogo en línea en sus dos versiones permite búsquedas de "mapas" como formato o tipo de material ${ }^{33}$, identificando de este modo las piezas que pertenecen a la Mapoteca. Sin perjuicio de las posibilidades de búsqueda por autor, fecha o editor, no cabe

33 A saber: Catálogo de la Biblioteca Nacional Digital de Chile http://descubre.bibliotecanacional.cl/primo_library/libweb/action/search.do?\&vid=BNC y Catálogo Bibliográfico de la Biblioteca Nacional, http://www.bncatalogo.cl/F?func=find-b-O\&local_base=BNC 
duda que el catálogo actual, lo mismo que el fichero en papel, privilegia el referente territorial como criterio de búsqueda. Como resultado, la Mapoteca nos permite identificar los objetos cartográficos datados que existen para un mismo lugar o espacio. En este caso también queda en un segundo plano la cuestión de la pertenencia del mapa a una serie (o fondo), lo mismo que las preguntas que pudieran surgir de esta inscripción.

La formación de catálogos digitales es parte de un programa de mayor alcance que involucra a la Biblioteca, y al Archivo Nacional por medio de la Dirección de Bibliotecas, Archivos y Museos, y que apunta a reconfigurar las relaciones entre las dimensiones análoga y digital, cuestión que impacta evidentemente en los lectores, los textos, sus soportes, y las lecturas, lo cual, dicho por Chartier respecto de las revoluciones del libro (2000: 13-20), puede pensarse igualmente respecto de las cartografías ${ }^{34}$.

Ya hemos llamado la atención sobre algunos efectos provocados por esta migración a lo digital, que impactan en el paisaje cartográfico que se configura ante los ojos de quien se acerca a estas colecciones.

Me parece relevante pensar igualmente en la materialidad específica de lo digital, para no plantear la cuestión en los términos binarios material/inmaterial ${ }^{35}$. La nueva interfaz de la pantalla y los programas de manejo de imágenes habilitan experiencias antes insospechadas: se puede observar, contrastar, comparar, pero también guardar, asociar y compartir, todo esto en la superficie de una pantalla de computador, adoptando casi infinitas modulaciones (imágenes duplicadas, ampliadas, recortadas, con la paleta de colores alterada intencional o casualmente, con vínculos a apuntes, textos, u otras imágenes). Por otra parte, la imagen digital nos aleja del objeto y lo que este comunica en su condición de presencia efectiva: las dimensiones del mapa tal como son vividas en relación con la experiencia sensorial propia; el grosor del papel; la expresión que comunican la intensidad de los trazos manuscritos, o el desgaste del molde tipográfico; las inscripciones al reverso de la obra (un sello institucional, las huellas del uso intensivo, por no mencionar anotaciones con diversas temporalidades); $y$, si corresponde, el lugar del mapa en relación con el objeto libro, volumen o legajo que pueda contenerlo, y su relación con los otros elementos que constituyen dicha unidad (otros mapas, otras imágenes, textos, títulos, índices, etc.). Todas estas cuestiones pueden verterse en una ficha de catalogación, aunque no siempre se haga (lo más común es la referencia a las dimensiones de la imagen y/o de la superficie que la contiene; el registro de anotaciones textuales existentes al reverso; y alguna indicación respecto de la técnica; por ejemplo, tinta o acuarela). Sin embargo, incluso si la ficha contuviera ese nivel de detalle, la comprensión del objeto se ve transformada al sustituirse, el "caminar, tocar, mirar, pensar", por las múltiples operaciones que habilitan las herramientas de trabajo con imágenes digitales ${ }^{36}$.

Sin embargo, según la información a la que se accede hoy al realizar búsquedas específicas, se constata que ya no es posible acceder a la versión en papel de numerosos mapas digitaliza-

\footnotetext{
Schütte González, coordinadora general del proyecto Memoria Chilena, reflexiona sobre los cambios en los procesos de acopio y preservación, de espacios, servicios y de acceso requeridos e impulsados por una biblioteca que es "nacional, patrimonial, en la que coexiste tanto el original análogo como el digital" (2013: 141), en una nota publicada con ocasión del Bicentenario de la Biblioteca Nacional.

35 Véase Thrift (2005) y su reflexión sobre las pantallas como redes de percepción, aparatos epistemológicos y formas de habitar el mundo.

${ }_{36}$ La cita corresponde a la descripción que hace Yee (2007: 33) acerca de su experiencia en el archivo Le Corbusier. Véase igualmente en Yee (Ibid.: 34) la distinción de Sherry Turkle entre lo que la tecnología hace por nosotros y lo que nos hace a nosotros.
} 
dos, quedando la consulta limitada, al menos formalmente, a la imagen existente en la Biblioteca Nacional Digital ${ }^{37}$.

No puede cerrarse esta sección sin referir a la Sala Medina de la misma Biblioteca, cuya colección denominada Biblioteca Americana contiene "colecciones relativas a América, [...] verdaderos tesoros bibliográficos entre los que cuentan valiosísimos incunables del siglo XV con las primeras menciones sobre el Nuevo Mundo, raros y apreciados libros náuticos, geográficos y cosmográficos contemporáneos de la época de los descubrimientos [...] importantes textos historiográficos, literarios y científicos de los siglos XVI, XVII, XVIII y XIX" (Biblioteca Nacional de Chile, 2006: 25-27), nucleada en torno a la donación fundacional que hiciera José Toribio Medina ${ }^{38}$. Entre sus colecciones, resguarda "un interesante conjunto de grabados y fotografías y una mapoteca que incluye mapas coloniales manuscritos de inestimable valor" (Biblioteca Nacional de Chile, 2006: 27-28). La colección cartográfica está compuesta por cerca de "2.200 piezas de diferentes formatos. Incluye mapas coloniales manuscritos y diversos otros mapas impresos, tanto de la colección Medina como de algunas piezas de la colección Barros Arana" (Biblioteca Nacional de Chile, 2006: 38).

Aunque el catálogo digital y la Biblioteca Nacional Digital sean, al igual que para la Mapoteca, los instrumentos provistos para conocer y consultar el material cartográfico de la Sala Medina, en este caso, la sala misma, su monumentalidad, y el diálogo con el funcionario que atiende las solicitudes de consulta, sugiriendo eventualmente la revisión de otros materiales complementarios, se constituyen en un repertorio de mediaciones adicionales que impactan en el contacto con la pieza.

\section{Mapoteca de la Facultad Arquitectura y Urbanismo de la Universidad de Chile}

Por la relevancia de algunas de sus colecciones patrimoniales, me detengo ahora en la Mapoteca de Biblioteca Central de la Facultad de Arquitectura y Urbanismo de la Universidad de Chile, donde encontramos otra constelación de determinaciones externas a los objetos, que modula nuestra comprensión de los mismos.

Esta Mapoteca tiene una historia reciente, vinculada con la incorporación de la Escuela de Geografía a la Facultad de Arquitectura y Urbanismo en 1985. La nueva casa de la Mapoteca, que se inaugura en democracia en $1991^{39}$, cierra una secuencia de acontecimientos y transformaciones institucionales vinculados con la intervención militar y el desmembramiento de la Universidad de Chile, obra de la dictadura. Esa es la historia reciente.

37 Al consultar, por ejemplo, por los ejemplares disponibles del mapa "Santa Cruz [material cartográfico]: San Fernando - Santa Cruz - San Vicente / Instituto Geográfico Militar de Chile. Reimpr. - Santiago de Chile: El Instituto, 1956", se obtiene la siguiente información: "La biblioteca no tiene ejemplares disponibles para ser prestados en sala. Por favor verifique si hay una copia digitalizada a la que pueda acceder en la plataforma Biblioteca Nacional Digital".

38 "Con cerca de 32.000 títulos y 378 volúmenes de manuscritos, [la Colección Americana] representa por su naturaleza, extensión y excepcional valor, el principal fondo patrimonial de la Biblioteca Nacional de Chile" (Biblioteca Nacional de Chile, 2006: 23).

39 Documento inédito; s/a, s/f, s/título, con información relativa a la Mapoteca. Gentileza de la encargada de la sección Mapoteca de la Biblioteca Central, Facultad de Arquitectura y Urbanismo, señora Verónica Balboa. 
Al mismo tiempo, la mapoteca tiene una historia más antigua, anclada en la relación entre formación pedagógica y acción estatal. El Instituto de Geografía -creado en 1942 al alero de la Facultad de Filosofía y Educación- cristaliza una relación orgánica que remota al siglo XIX, con la formación de los primeros ingenieros en geografía y minas, y la ampliación de la docencia en el campo de la geografía, al fundarse en 1889 el Instituto Pedagógico ${ }^{40}$. En la colección cartográfica quedan huellas de dicha historia pasada que materializa el vínculo con el Estado y la provisión de profesionales para su acción: "Allí se conectaban arquitectos e ingenieros para cumplir la misión encomendada de hacerse cargo de las obras públicas, lo cual puede explicar el origen mayoritario del acervo de la mapoteca: la Dirección General de Obras Públicas" (Araya, 2011: 174); a este corpus vino a agregarse una importante colección de planos y mapas que donó a la Universidad el Ministerio de Tierras y Colonización (bajo el mandato del presidente Alessandri, a principios de la década de 1960) ${ }^{41}$. El corpus lo integran igualmente documentos cartográficos manuscritos de comisiones exploradoras, como aquella que se organizó en 1900 al río Aysén, a cargo de Bracey Wilson; Planos de Santiago confeccionados con diferentes finalidades, en especial, varios relacionados con las obras del Centenario: canalización del Mapocho, parque Cousiño (hoy Parque O'Higgins), etc.; Planos de haciendas, minas, cuencas hidrográficas, otras ciudades. También forman parte de su colección objetos cartográficos tales como cartas geológicas, geomorfológicas, náuticas, fotografías aéreas y fotomosaicos (Araya, 2011: 175-177).

La Mapoteca está hoy alojada en una sala de la Facultad de Arquitectura y Urbanismo: los mapas mismos se ubican en diferentes planeras y estanterías. El espacio es amplio, tiene mesas de luz, acuden estudiantes a preparar planos y maquetas para sus actividades académicas (Figura No 5).

En el mismo recinto se encuentra un mueble con fichas de cartón que contienen una versión desactualizada del catálogo que ya no se consulta, -herencia de la época de instalación de la mapoteca en este espacio-, y una atenta encargada de sala, en cuyo terminal de computación existe un registro parcial de mapas, ordenados en una planilla excel en que se consignan los mapas de las diferentes regiones del país. Por último, algunos de estos mapas -aquellos que se ha considerado patrimonialmente más importantes-, están además incorporados al catálogo en línea de la Biblioteca de la Universidad, que integra desde 2017 la plataforma de la Biblioteca Digital de la Universidad de Chile (https://www.bibliotecadigital.uchile.cl) ${ }^{42}$.

\footnotetext{
40 Los antecedentes de esta trayectoria remontan a la creación de la Facultad de Filosofía y Humanidades en 1842 (llamada en su tiempo de Humanidades, de Filosofía, de Humanidades y Bellas Artes, y de Filosofía y Educación); la fundación del Instituto Pedagógico para otorgar una formación universitaria profesional al profesorado de educación secundaria en 1889 (sus profesores pertenecen tanto a la Facultad de Filosofía como a la de Matemáticas); a la creación del Instituto de Geografía, en 1942; al traslado de dicha Facultad al campus Macul (1950); y a su consolidación como una instancia de docencia e investigación bajo el rectorado de Juan Gómez Millas (1953-1963).

El golpe de Estado de 1973 y la intervención militar en la vida universitaria, cristalizan en 1981, al dictarse la ley de transformación general del sistema de educación en el país, que abarca la transformación del sistema universitario. Junto con crearse las universidades privadas; se separan las sedes regionales de la Universidad de Chile como instituciones estatales autónomas; y, en ese mismo marco, se crea la Academia Superior de Ciencias Pedagógicas como otra institución independiente, que da origen a la UMCE, un hito fundamental de la formación de la actual Facultad de Filosofía y Humanidades, y de la intervención y posterior incorporación en 1985 de Geografía a la Facultad de Arquitectura y Urbanismo (Universidad de Chile, 1942; Mellafe, Rebolledo y Cárdenas, 1992; Araya, 2011).

41 Este incluye material recolectado o producido por la Oficina de Mensura de Tierras de esa repartición estatal que funcionó entre 1907 y 1914 (y que reúne la Oficina de Límites, la sección Topográfica de la llamada Oficina de Inspección de colonización, la de Radicación indígena) (Álvarez Correa, 2000)

42 Según noticia de abril de 2016, "Mapoteca FAU: cartografía histórica y revistas para la comunidad" habría cerca de 650 mapas digitalizados (ver http://www.fau.uchile.cl/noticias/120509/mapoteca-fau-cartografia-historica-y-revistas-para-la-comunidad).
} 
Figura $\mathrm{N}^{\circ} 5$

Mueble vertical para mapas murales, Mapoteca de la Biblioteca Central, Facultad de Arquitectura y Urbanismo, Universidad de Chile

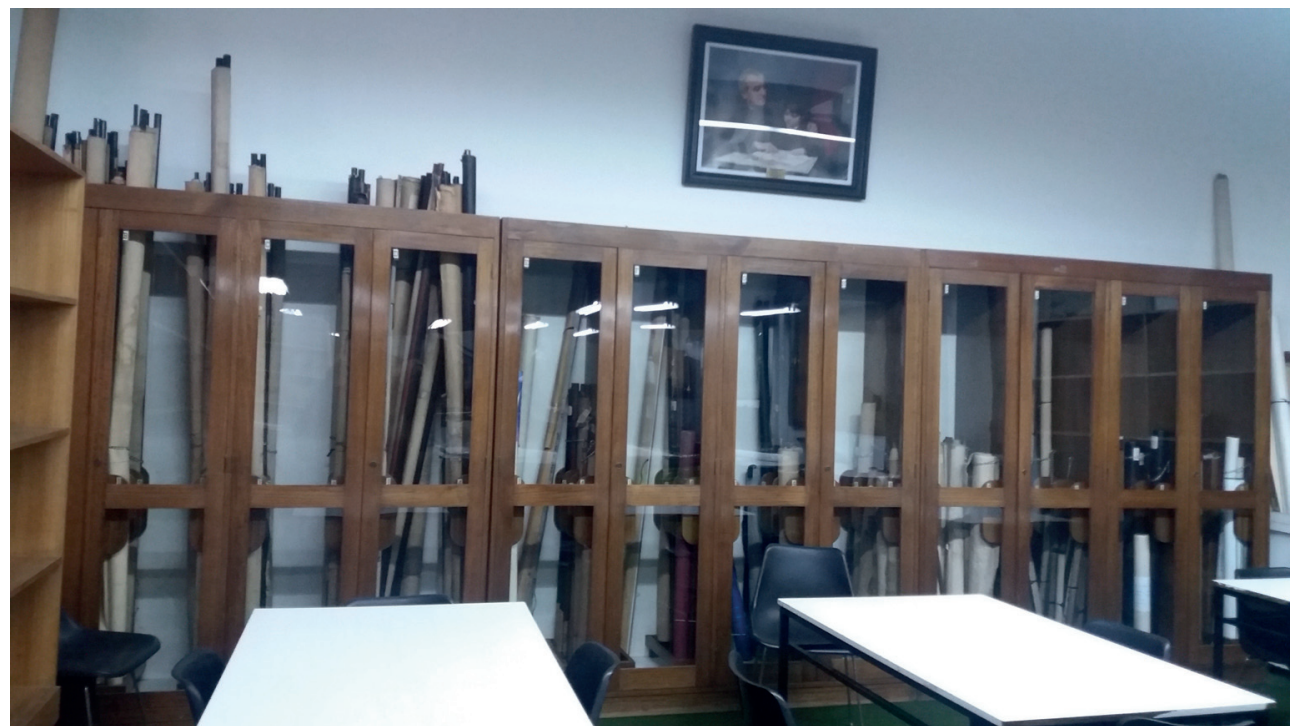

Fuente: Archivo fotográfico personal de la autora.

Las planeras contienen un repertorio rico y variados de objetos, muchos de ellos no catalogados, y que se pueden revisar uno a uno con paciencia contando con la autorización de la encargada de la sala. Esta condición habilita un contacto con los materiales resguardados por la mapoteca que no es habitual. La disposición de los mapas en las planeras permite reconocer, en algunos casos, la pertenencia a una serie o colección. Al mismo tiempo, la organización del material por zona geográfica en el computador de la encargada de esta colección sugiere un énfasis en la visualización de los diferentes objetos cartográficos que la colección posee para cada área o localidad.

\section{Biblioteca y Mapoteca del Instituto Geográfico Militar}

Tanto la mapoteca de la Biblioteca Nacional como la de la Facultad de Arquitectura y Urbanismo de la Universidad de Chile resguardan materiales producidos por el Instituto Geográfico Militar el que, a su vez, posee su propia mapoteca.

La Biblioteca y Mapoteca Ramón Cañas Montalva es una institución dependiente del Instituto Geográfico Militar (IGM) perteneciente al Ejército de Chile. El IGM fue creado en 1922 como "organismo especializado del Ejército que tiene como misión fundamental efectuar la representación gráfica de todo el territorio nacional en mapas, cartas geográficas y planos topográficos" (IGM, 2004: i). Desde 1930, con la dictación de la llamada Ley de la Carta, es "la autoridad oficial, en representación del Estado, en todo lo que se refiere a la geografía, levantamiento y elaboración de 
cartas del territorio nacional" (IGM, 2004: 70-71) ${ }^{43}$. Sin embargo, esta tarea tiene antecedentes en el siglo XIX, tanto en lo referido a la elaboración de cartas oficiales del país, como a la recopilación de material cartográfico ${ }^{44}$.

Una reorganización del IGM en 1929 lleva a la creación de una biblioteca, además de otras reparticiones como la sección estadística y cálculo, artes gráficas, publicaciones, almacén de instrumentos, archivo de registros y recopilación de cartas (IGM, 2004: 69)45. En esta etapa, la Biblioteca presta servicios al personal del Ejército ${ }^{46}$. La mapoteca propiamente tal es posterior, y puede datarse en la década de 1950. En 2012 se contrata personal especializado quien asume la tarea de organizar la colección, que hasta ese momento no contaba con catálogo ni inventario ${ }^{47}$.

De manera complementaria, el IGM posee un archivo, donde se resguarda importante material cartográfico, de cuya organización desde principios del siglo XX quedan huellas en la documentación de la institución ${ }^{48}$.

Lo que antes fue un servicio para el personal del Ejército se ha abierto para el público general. La sala que ocupa actualmente la mapoteca se construyó en 1971, al ampliarse las dependencias del IGM inauguradas en $1929^{49}$. Se encuentra allí mismo el museo cartográfico: una exposición de instrumentos y registros que dan cuenta de la historia del levantamiento de la cartografía oficial del país. Aunque tiene un ingreso propio por calle Dieciocho (Figura $N^{\circ} 6$ ), este no está habilitado por lo que el acceso a la mapoteca debe hacerse a través de la oficina de guardia, que controla la entrada a todo el recinto militar.

${ }^{43}$ Corresponde al DFL. n 2.090. "“El Decreto supremo que dio vida a esta importante repartición en 1922 no fue lo suficientemente claro como era de esperar, y algunas actividades cartográficas continuaron realizándose en forma dispersa y por distintos estamentos, como ministerios o entidades particulares que buscaban satisfacer sus propias necesidades" (IGM, 2004: 71)

44 Durante el periodo de la Independencia, Bernardo O’Higgins funda los "Depósitos Cartográficos" "para mantener los planos y mapas de las ciudades y territorios necesarios para la campaña libertadora". En 1891, se crea "la Oficina Geográfica, dependiente del Estado Mayor del Ejército, encargada de elaborar la carta militar del país, la que será la base del futuro IGM". Nuevas transformaciones en 1893, 1898, 1903, 1905, 1906 y van prefigurando la creación, en 1922, del IGM (IGM, 2004: 53-54; 58-59).

45 En los primeros anuarios de la institución, se consigna ya la actividad de acopio de materiales para la biblioteca por medio del canje y la adquisición (IGM, 1932: 98).

46 Según se consigna en una publicación institucional de 1929, la organización del IGM está constituida por la Dirección general y tres departamentos: geodésico, topográfico y cartográfico. La dirección tiene un Consejo Técnico y una serie de Secciones, entre las que destaca la Sección Estadística, que acoge la Biblioteca, y Publicaciones (IGM, 1929: 4).

El Anuario de 1932-1935 da cuenta del funcionamiento de la biblioteca: "Ha funcionado normalmente prestando muy útiles servicios al personal a pesar de la reducida dotación de obras técnicas que posee" (IGM, 1935: 70).

47 Información entregada por Leslie Villanueva, Jefa de la Biblioteca, Mapoteca y Museo del Instituto Geográfico Militar con ocasión de visita en mayo de 2016.

48 El "Anuario del Instituto Geográfico Militar n¹" consigna la existencia de un "Archivo técnico del Instituto" dividido en el Archivo de Registros geodésicos y Archivo de registros topográficos: "En este archivo se encuentran catalogados por material todas las monografías, registros y cálculos relativos a los trabajos astronómicos, geodésicos y de nivelación ejercitados por este Instituto, en tal forma que en todo momento se puede recurrir a él en demanda de un dato o estudio cualquiera [y]. Archivo de registros topográficos, "se encuentra la documentación correspondiente a las 305 hojas topográficas a que alcanza actualmente el levantamiento regular a escala 1:25.000" (IGM, 1932: 80).

49 "El pabellón iniciado el año 1927 está ya concluido y en él tiene su dependencia el Departamento cartográfico. Consta de un subsuelo, y una azotea. El piso superior lo ocupa la sección de Reproducciones gráficas (fotografía y fotograbado). El segundo piso está ocupado por la Sección de Cartografía. Es una grande y hermosa sala de 30 metros. de largo y 10 de ancho, ampliamente alumbrada. Los talleres gráficos ocupan el primer piso y en el subsuelo están los materiales de imprenta, archivo, etc." (IGM, 1929: 5). 
Figura $\mathrm{N}^{\circ} 6$

Fachada de la Biblioteca y Mapoteca Ramón Cañas Montalva del Instituto Geográfico Militar, actualmente no habilitada para circulación de público

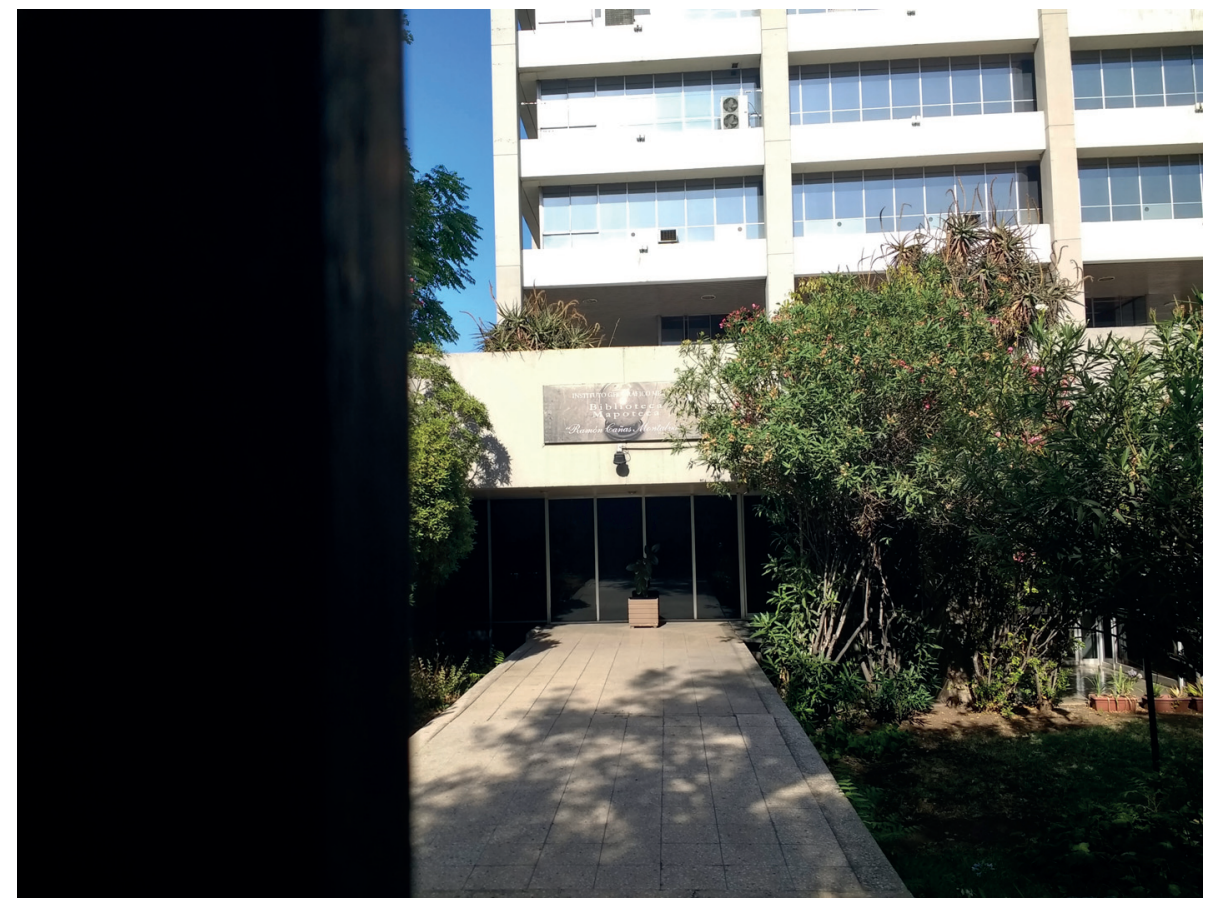

Fuente: Archivo fotográfico personal de la autora.

En tal sentido, las mediaciones son desconcertantes, pues oscilan entre el control formal ejercido por la autoridad militar en el espacio y la disposición a la colaboración del personal que trabaja en la Biblioteca. A diferencia de todas las otras mapotecas revisadas, esta mantiene una unidad orgánica con la institución en la que se origina, en la medida que sus colecciones se remontan a la labor de levantamiento topográfico y geodésico exigida a los ingenieros militares, a la formación de los militares del país y al mandato vigente de levantar y mantener la cartografía terrestre del Estado de Chile.

La consulta de los mapas de la colección nos coloca ante circunstancias y reglas curiosas. Solo se prestan mapas históricos o desactualizados, según como se quiera calificarlos; o bien aquellos que, por alguna razón, no pueden ser consultados en la Biblioteca Nacional. De lo contrario, no se prestan, pues están a disposición de quien quiera comprarlos en el salón de ventas de la institución. Por último, las peticiones de consulta se hacen por correo, las que se revisan y visan por el personal militar del IGM ${ }^{50}$. En tal sentido, se trata de una mapoteca de carácter público, pero no abierta a consulta inmediata ni universal.

Según información de 2016, los procesos de inventario y catalogación están en curso. No existe un catálogo digital abierto al público, sino uno que maneja el encargado de la sala y que se 
puede consultar por autor, localidad, año, título, etc. El catálogo impreso, que incluía un detallado índice temático y toponímico que tuvimos ocasión de revisar en nuestras primeras visitas, ya no está disponible ${ }^{51}$.

\section{Conclusiones}

Terminado este recorrido, caben acá algunas conclusiones parciales que retomo a partir de la evocación de un libro clásico: "Le gôut de l'archive" de Arlette Farge (1989). De su obra, me interesan en esta ocasión dos imágenes. La primera es la imagen del archivo como la acumulación desmedida de papeles, herencia de un tiempo y unas circunstancias pasadas, cuyas lógicas de formación y pervivencia siempre se nos escapan parcialmente. La segunda es la imagen del archivo como una materialidad presente hecha de legajos, cajas, cintas, estantes, pasillos, con olores y texturas; una materialidad dispuesta en un espacio; y también actitudes heredadas y rápidamente adoptadas por quienes acuden por primera vez a su consulta. Me parece que estas imágenes pueden vincularse con las ideas presentes en una conferencia que dictó el archivero canadiense Terry Cook en el Archivo Histórico Nacional en Madrid en 2010 cuyo título es "Landscapes of the past" ${ }^{\prime 2}$. En su presentación, Cook adopta una posición que me recuerda con detalle el texto de Farge, porque llama a sospechar del uso inmaterial del concepto de archivo, dicho en singular, y a atender, en vez, a la existencia plural de archivos: instituciones hechas de personas, que se transforman en el tiempo y en su ubicación espacial, y que han puesto en obra asunciones, creencias, teorías, estrategias, metodologías y procedimientos diversos para continuamente dar forma a los registros archivísticos y su ordenamiento.

Sin desconocer las relaciones históricas que pueden trazarse entre archivo y poder, y su impacto en cómo estas han organizado la fijación de ciertos discursos, habilitando unas voces por sobre otras para nombrar, visibilizar, jerarquizar o controlar, me he interesado en el polo de la materialización de dichos discursos vertidos en papeles y, en particular, en la dimensión material de las mapotecas, poniendo atención a las condiciones en que trabajamos con los registros cartográficos del pasado, a los cuales accedemos fruto de un repertorio discreto de operaciones.

Hemos sugerido que las mapotecas estudiadas, que se forman en las últimas décadas del siglo $X X$, recogiendo un continuo de prácticas previas, ponen en obra una visión naturalizada del mapa como instrumento perfectible. Esta idea se expresa en la comprensión de los documentos que se resguardan como materializaciones concretas de un referente particular: mapas diversos, que pueden ser datados, y que representan un territorio a partir de los conocimientos y las técnicas disponibles al cartógrafo en cuestión. Visibilizar los mapas según el territorio representado tiene como efecto invisibilizar, o al menos dejar en segundo plano, la práctica cartográfica entendida no como expresión de condiciones técnicas, sino de procesos históricos complejos que llaman a unos u otros a poner el mundo en el mapa. Hemos visto en particular, que queda oculta la distinción entre colección y fondo de archivo, inhibiendo nuestro conocimiento respecto de las prác-

Información de visita, mayo de 2016

52 La conferencia ha sido editada en español, refiero a ella en la bibliografía, aunque retengo el título del inglés, "landscapes of the past" y su traducción precisa como "paisajes", y no aquel adoptado en la versión castellana (Panoramas del pasado). 
ticas involucradas en la secuencia que va de la producción del mapa a su registro en un catálogo de una institución.

Por otra parte, me he interesado en el peso de lo material en la configuración de lo visible, indagando en los efectos de las materializaciones del catálogo en libros o impresos, en ficheros y en soporte digital; las articulaciones entre mapa, mobiliario, sala de consulta y bodega; las especificidades de la experiencia sensorial y cognitiva que ofrecen tanto el acceso digital como el contacto con el mapa; las posibilidades de contacto con el corpus cartográfico que abarcan desde el acceso abierto y universal (al menos en teoría) al control reglamentado o mediado por las personas que trabajan en las mapotecas. Esta indagación me ha permitido corroborar el impacto que tienen estas mediaciones en lo que queda a la vista del usuario.

He sugerido denominar paisajes cartográficos al corpus cartográfico tal como se nos presenta fruto de estos efectos de visibilización. Al modo que lo hace la pintura de paisajes, los mapas parece que estuvieran simplemente "alli", que pudiéramos mirarlos a través de una ventana, naturalmente, cuando en efecto lo que observamos es resultado de sucesivas inscripciones institucionales, y de las huellas de esa historia en nuestro presente. Reconocer esas mediaciones permite profundizar en nuestra comprensión de las relaciones entre sociedad, territorio y prácticas de conocimiento.

\section{Referencias bibliográficas}

ABELL, R. Catalogación y clasificación de los mapas en las bibliotecas mexicanas. Memorias del seminario nacional de mapotecas. México: Seminario Nacional de Mapotecas, CETENAL, 1977, p. 123-150.

ACERVO. Entrevista con Maria Dulce de Faria. Acervo, 2016, Vol. 29, № 1, p. 9-30.

ALARCÓN, J. Biblioteca nacional de Chile. Aportes para su historia. Mapocho. Revista de Humanidades, 2013, N 73, p. 43-104.

ALARCÓN, J.; APABLAZA, J. y GUZMÁN, M. Revistas Culturales Chilenas del Siglo XX. Índice General. Santiago de Chile: Consejo Nacional de la Cultura y las Artes, Fondo Nacional de Fomento del Libro y la Lectura, 2006.

ÁLVAREZ CORREA, L. Cartografía y geodesia: las innovaciones de la Oficina de Mensura de Tierra de Chile a principios del siglo XX (1907-1914). Scripta Nova. Revista Electrónica de Geografía y Ciencias Sociales, 2000, № 69. Disponible en Internet: http://www.ub.edu/geocrit/sn-69-12.htm

ANDERSON, B. Comunidades imaginadas. Reflexiones sobre el origen y la difusión del nacionalismo. México: FCE, 1993.

APPADURAI, A. (editor). La vida social de las cosas: perspectiva cultural de las mercancías. México: Consejo Nacional para la Cultura y las Artes, 1991 [1986]. 
ARAYA, A. Materia y memoria. Tesoros de la Universidad de Chile. Santiago de Chile: Tinta Azul, Ediciones de la Universidad de Chile, 2011.

ARCHIVO NACIONAL. Archivo Nacional. Colección Chile y su Cultura. Santiago de Chile: Dirección de Bibliotecas, Archivos y Museos, Ministerio de Educación Pública, 1983.

BAUDRILLARD, J. El sistema de los objetos. México: Siglo XXI, 1999.

BESSE, J.M. Voir la terre. Six essais sur le paysage et la géographie. Le Méjan: Actes Sud, 2000.

BIBLIOTECA NACIONAL DE CHILE. Biblioteca Nacional. Colección Chile y su Cultura. Santiago de Chile: DIBAM, 1982.

BIBLIOTECA NACIONAL DE CHILE. Biblioteca Nacional de Chile. 1813-1988. Santiago de Chile: Editorial Andrés Bello, 1989.

BIBLIOTECA NACIONAL DE CHILE. Biblioteca Nacional de Chile. Memoria de Actividades. 19961997. Santiago de Chile: DIBAM,1998.

BIBLIOTECA NACIONAL DE CHILE. Biblioteca Nacional de Chile. 190 años de historia. 1813-2003. Santiago: DIBAM, 2003.

BIBLIOTECA NACIONAL DE CHILE. Biblioteca Nacional de Chile: historia de las colecciones: Colección José Toribio Medina: 193 años de historia 1813 - 2006. Santiago de Chile: La Biblioteca, 2006.

BIBLIOTECA NACIONAL DE CHILE. Biblioteca Nacional. Chile. 200 años. Memoria anual 2012. Santiago de Chile: DIBAM/Biblioteca Nacional, 2013.

CAUQUELIN, A. L'invention du paysage. Paris: Presses Universitaires de France, 2000.

CHARTIER, R. Las revoluciones de la cultura escrita. Diálogo e intervenciones. Barcelona: Gedisa Editorial, 2000.

COMISION DE NORMAS ESPAÑOLAS DE DESCRIOCIÓN ARCHIVISTICA (CNEDA). Vocabulario para la descripción archivística. Madrid: Ministerios de Educación, Cultura y Deporte, 2017. Disponible en Internet: https://es.calameo.com/read/000075335e4afa63098df

COMITÉ NACIONAL DE LA MEMORIA DEL MUNDO. Archivos en Chile. Miradas, Experiencias y Desafíos. Santiago de Chile: UNESCO/DIBAM, 2016.

COOK, T. Panoramas del pasado: archiveros, historiadores y combates por la memoria. Tabula, 2010, No13, p. 153-166.

CRUZ MUNDET, J.R. Manual de Archivística. Madrid: Fundación Germán Sánchez Puiérez/Pirámide, 1994. 
CRUZ MUNDET, J.R. Administración de documentos y archivos. Textos fundamentales. Madrid: Coordinadora de Asociaciones de Archiveros, 2011.

DESCALLÉES, A. y MAIRESSE, F. (editores). Key Concepts of Museology. París: Armand Colin/ICON, 2010.

DESCOLA, PH. La fabrique des images. Anthropologie et Sociétés, 2006, Vol. 30, N 3, p. 167-182. Disponible en Internet: http://id.erudit.org/iderudit/014932ar

EDNEY, M. Putting 'Cartography' into the History of Cartography: Arthur H. Robinson, David Woodward, and the Creation of a Discipline. Cartographic Perspectives, 2005, № 51, p. 14-29.

FACULTAD DE ARQUITECTURA Y URBANISMO. Noticias. Mapoteca FAU: cartografía histórica y revistas para la comunidad. Miércoles 13 de abril de 2016. Disponible en Internet: http://www.fau. uchile.cl/noticias/120509/mapoteca-fau-cartografia-historica-y-revistas-para-la-comunidad

FARGE, A. Le gôut de l'archive. Paris: Le Seuil, 1989.

FORTEY, R. Dry Storeroom No. 1: The Secret Life of the Natural History Museum. New York: Knopf, 2008.

GEOGRAPHY \& MAP READING ROOM. History and Background. S/F. Disponible en Internet: https://www.loc.gov/rr/geogmap/gmhist.html

GOMBRICH, E.H. Norma y Forma. Estudios sobre el arte del Renacimiento I. Madrid: Debate, 1984.

HARLEY, J.B. The Map and the Development of the History of Cartography. In: HARLEY, J.B. \& WOODWARD, D. (editors). The History of cartography, vol. 1: Cartography in Prehistoric, Ancient, and Medieval Europe and the Mediterranean. Chicago: University of Chicago Press, 1987, p. 1-42.

HARLEY, J.B. The New Nature of Maps. Essays in the History of Cartography. Baltimore and London: The John Hopkins University Press, 2001.

HEREDIA HERRERA, A. Archivística general. Teoría y práctica. Sevilla: Servicio de Publicaciones de la Diputación de Sevilla, 1991.

HIDALGO, R.; SÁNCHEZ, R.; ARENAS, F. y SANTANA, D. El desarrollo de la ciencia geográfica en América Latina. La producción científica a través de Revista de Geografía Norte Grande. Revista Geografía Norte Grande, 2015, No 60, p. 7-20.

HOLLMAN, V. y LOIS, C. Geo-grafías. Imágenes e instrucción visual en la geografía escolar. Buenos Aires: Paidós, 2015.

INSTITUTO GEOGRÁFICO MILITAR. El Instituto geográfico militar. Santiago de Chile: Ejército de Chile: 1929. 
INSTITUTO GEOGRÁFICO MILITAR. Anuario del Instituto Geográfico Militar Nํ1, 1891-1932. Santiago de Chile: Ejército de Chile, 1932.

INSTITUTO GEOGRÁFICO MILITAR. Anuario del Instituto Geográfico Militar, 1932-1935. Santiago de Chile: Ejército de Chile, 1935.

INSTITUTO GEOGRÁFICO MILITAR. Historia del Instituto Geográfico Militar y su aporte al desarrollo Nacional. Santiago de Chile: IGM, 2004.

JACOB, CH. L'empire des cartes. Approches théoriques de la cartographie à travers l'histoire. Paris: Bibliothèque Albin Michel, 1992.

LOIS, C. Mapas para la Nación. Episodios en la historia de la cartografía argentina. Buenos Aires: Biblios, 2014.

MAPOTECA ARCHIVO NACIONAL DE CHILE. S/F. Disponible en Internet:

http://www.archivonacional.cl/sitio/Secciones/Servicios/Mapoteca/

MAPOTECA BIBLIOTECA NACIONA DE MEXICO. S/F. Disponible en Internet:

http://bnm.unam.mx/index.php/fondo-contemporaneo/sala-de-mapoteca

MAPOTECA MANUEL OROZCO Y BERRA. S/F. Disponible en Internet:

https://www.gob.mx/siap/articulos/mapoteca-manuel-orozco-y-berra-27322

MAPOTECA SALA MANUEL SALVA. S/F. Disponible en Internet:

https://www.bn.gov.ar/biblioteca/salas/mapoteca

MELLAFE, R.; REBOLLEDO, A. y CÁRDENAS, M. Historia de la Universidad de Chile. Santiago de Chile: Ediciones de la Universidad de Chile. Biblioteca Central, 1992. Disponible en Internet: http:// libros.uchile.cl/188

MIRANDA ESPIZANOZA, M. Organización de la unidad mapoteca (apuntes de clases). Santiago de Chile: CONICYT, 1980.

MUZZOPAPPA E. y VILLALTA, C. Los documentos como campo. Reflexiones teórico-metodológicas sobre un enfoque etnográfico de archivos y documentos estatales. Revista Colombiana de Antropología, 2011, Vol. 47, N 1, p. 13-42.

OLSEN, B. Material culture after text: remembering things. Norwegian Archeological Review, 2003, Vol. 36, No 2, p. 87-104.

PARRY, R.B. \& PERKINS, C. R. The Map Library in the New Millennium. Chicago/Londres: ALA Editions/LA Publishing, 2001.

PORTUONDO, M. Ciencia secreta. La cosmografía española y el Nuevo Mundo. Frankfurt am Main: Iberoamericana/Vervuert, 2013. 
REVISTA QUÉ PASA. Patricio Estellé. obituario. Archivo de Referencias Críticas. Disponible en Internet: http://www.bibliotecanacionaldigital.cl/bnd/628/w3-article-223974.html

SCHÜTTE GONZÁLEZ, D. El desafío de la Biblioteca nacional Digital de Chile. Mapocho. Revista de Humanidades, 2013, № 73, p. 141-144.

LUZES, J.S. O público e o privado: solicitacoes do Instituto Histórico e Geográfico Brasileiro (IHGB) ao Conselho Federal de Cultura. En: Seminario Internacional "Políticas culturais". Rio de Janeiro: Fundacao Casa de Rui Barbosa, 2014.

THRIFT, N. Beyond Mediation: Three Forms of New Material Registers and Their Consequences. In: MILLER, D (editor). Materiality. Durham and London: Duke University Press, 2005, p. 231-255.

UNIVERSIDAD DE CHILE. Universidad de Chile: 1842 - 1942. Santiago de Chile: Editorial Universidad de Chile, 1942. Disponible en Internet: http://libros.uchile.cl/535

VERDIER, N. La carte Avant les cartographes. L'avènement du régime cartographique en France au XVIIlè siècle. Paris: Publications de la Sorbonne, 2015.

WILLIAMS, R. Marxism and Literature. Oxford/New York: Oxford University Press, 1977.

WOODWARD D. \& LEWIS, G.M. Introduction. In: WOODWARD, D. \& LEWIS, G.M (editors). The History of Cartography, Vol. 2. Cartography in the Traditional African, American, Arctic and Australian and Pacific Societies. Chicago \& London: The University of Chicago Press, 1998, p. 1-10.

YEE, S. The Archive. In: TURKLE, S. (Ed.). Evocative objects. Things We Think With. Cambridge, Mass/London: The MIT Press, 2007, p. 30-37. 
